\title{
Electronic Module Based on Outdoor Learning for Thematic Learning of Elementary School
}

\author{
Susi Suryani ${ }^{1}$, Chatarina Muryani $^{2}$, Yasin Yusup ${ }^{3}$ \\ \{ susisuryani2211@ student.uns.ac.id ${ }^{1}$ \} \\ ${ }^{1}$ Postgraduate Program of Geography Education, Sebelas Maret University, Indonesia \\ ${ }^{2,3}$ Postgraduate Departement, Sebelas Maret University, Indonesia
}

\begin{abstract}
The aim of this study was to describe the students and teachers need for teaching material of electronic module based on outdoor learning to improve the learning outcomes on the material of our friend's environmental in elementary school students. This study used qualitative research. The research approach used a descriptive approach. This study was conducted at the elementary school of Klaten, Indonesia. The sampling technique in this study used purposive random sampling. Data collection technique used observation, interview, and document analysis. The technique of checking the validity of the data used triangulation technique. Data analysis in this study referred to qualitative analysis. Based on the result of observation, interview, and document analysis, it can be concluded that the use of teaching material was still in the form of textbooks only and still did in the classroom on the material of our friends' environmental, in which it should be focused on environmental experience in elementary school. Based on this data, it was necessary to develop an teaching material of electronic module based on outdoor learning so that learning was more meaningful tailored to the students and teacher need of an elementary school in thematic learning.
\end{abstract}

Keywords: need analysis, teaching material, electronic module, outdoor learning, thematic

\section{INTRODUCTION}

Education is the most basic and most important thing in the process of national progress. Today, we are entering at 21 st-century education supported by informatic technology. This education is expected to be able to improve students' learning outcomes that are more meaningful, active and creative. In this century, Indonesian education was carried out with the 2013 curriculum which put forward the achievement of cognitive, psychomotor and effective result at the senior high school, junior high school and elementary school levels.

In elementary school education, the learning process is done thematically with a holistic approach. This learning intends to maximize the development of the left brain that is achieved through academic and technical skills, as well as the right brain through social development and skill values [1]. This learning links experience directly in harmony with nature [2]. In the 
elementary school learning process, holistic learning is very appropriate because students are directed to be directly involved in the surrounding environment through the five senses.

In the process of elementary school thematic learning, learning activity can be measured from the process of interaction between students, teachers, and learning resources that become teaching material. The process of continuous education between teaching material has a very important role as an intermediary used to achieve the learning goals. The learning process can be more effective and efficient if teaching materials are available [3]. Teaching material is made in order to transfer the learning messages from teacher to student so that they can stimulate students' thoughts, feelings, interests, and willingness to learn [4]. The teaching material used in learning affects the breadth of knowledge acquired by students, as well as students' interest in learning. Teaching material has an important role in the learning process, and the availability of teaching material can assist students in obtaining the learning material [5].

Our friend's environmental material in thematic learning is one of the interesting material. This material focuses on real-life learning by approaching the five senses in the surrounding environment. The fact that happens at school is sometimes still far from what is expected. The use of learning devices should be tailored to the needs, environmental conditions, a previous preliminary study by [6] conducted at the fifth grade in an elementary school in Malang, Indonesia showed that thematic learning has not been well implemented. Teaching materials that are designed not to suit the needs, environmental conditions, characteristics of students and have not used the technological characteristics of students and have not used technology. In line with a study from [7] mentioned that the use of technology in the learning process is relevant, it can enhance the learning experience, encourage participation, collaboration, creativity, and involvement. Therefore, to achieve the expected goals, there is a need to manage the learning process through teaching material of electronic module that further activates students.

Teaching material of electronic module is one of the modules displayed with informatics technology which combines science process skills and dynamic motion content to improve skills. Giving material through the electronic module is able to develop the imagination of students, in addition to being supported by learning material module of our friend's environment, it will be more meaningful if students are invited to do learning outside the classroom.

According to Priest in [8] stated that education outside the classroom is an experimental method of learning while working, which takes place outdoors. Education outside the classroom aims at enabling students to adapt to the environment and natural surrounding and knowing the importance of life skills and life experiences in the surrounding environment. This is in line with what is revealed by [9] that one of the advantages of learning outside the classroom is that learning outside the classroom is able to act as a stimulus for critical creative thinking and provides opportunities and challenges to socialize with the environment. Therefore, the learning process is more meaningful. Based on the exposure to the problem, it is necessary to conduct a study related to the need analysis of outdoor learning based on teaching material of electronic module to improve the learning ability of elementary school students.

\section{METHOD}

This study used qualitative research with a descriptive approach. A descriptive approach was used based on the consideration that the problems to be studied are ongoing in the present which aims at analyzing phenomena that occurs in the surrounding environment.

The locations used in this study were two Elementary Schools in Klaten, Indonesia, namely Elementary School 01 Sidorejo, Elementary School 02 Sidorejo. The subjects used in this study 
were 56 students and 2 class teachers in the five schools. The time for conducting the study was at the second semester of Academic Year 2018/2019.

Data collection techniques in this study included observation, interview, and document analysis. The technique of checking the validity of the data in this study used triangulation technique. Triangulation technique was used to test the credibility of the data by checking the data to the same source with a different technique [10]. The results of the triangulation comparison were then concluded so as to obtain valid data. The triangulation technique was described as follows.

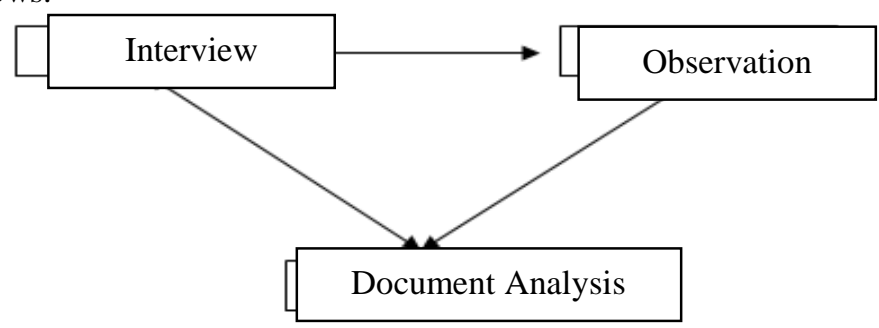

Figure 1. Triangulation technique

Data analysis in this study referred to the qualitative analysis stated by Miles and Huberman. The stages used in conducting data analysis were: data reduction, data display, conclusion and verifying [11].

\section{RESULT AND DISCUSSION}

This study aimed at describing the students and teachers need for teaching material of electronic module based on outdoor learning in elementary school students. The data on this need analysis is obtained through observation, interview, and document analysis. Need analysis in this preliminary study was carried out into two elementary schools in Klaten, namely Elementary School 01 Sidorejo, Elementary School 02 Sidorejo.

\subsection{Observation}

The observation was conducted by observing the activities carried out by teachers and fifthgrade students of elementary school. Based on the result of observation of the teacher and students during learning, an overview was obtained of: (1) The learning process on the material of our friend's environment in thematic learning still did in the classroom. (2) the teaching material used in the form of student worksheets.

The result observation showed that the use of teaching material was less attractive because they were limited to student worksheets and textbooks that had not been supported by visualization of images and videos. Learning was still monotonous so students were less enthusiastic. This was supported by the previous study from [12] that textbooks were less effective in helping students carry out the learning process based on the revised 2016 curriculum in 2013 with or without teacher assistance. In learning, students tended to only accept the subject matter through teacher explanations, without building their own knowledge through active experiments in the learning process in the immediate environment.

\subsection{Interview}

The interview was conducted to collect information about conditions of commonly used teaching material. In addition, the interview was also used to determine the teachers and students 
need for teaching material of electronic module based on outdoor learning. The interview was conducted with teachers and fifth-grade students at Elementary School 01 Sidorejo, Elementary School 02 Sidorejo. The result of the interview with two class teachers can be seen in the following table:

Table 1. Result of interviews with class teachers regarding the learning process

\begin{tabular}{|c|c|c|}
\hline No & Indicators & Discussions \\
\hline 1. & $\begin{array}{l}\text { Learning method } \\
\text { commonly used }\end{array}$ & $\begin{array}{l}\text { Both teachers in learning used to lecture, assignment, and } \\
\text { discussion method. Two teachers interviewed knew the learning } \\
\text { method that was based on the } 2013 \text { curriculum. }\end{array}$ \\
\hline 2. & Teaching material used & $\begin{array}{l}\text { The learning media used were printed teaching material such as } \\
\text { textbook and teacher discussion. There was an LCD but it was } \\
\text { rarely used. Internet technology was still rarely used in the } \\
\text { learning process at the school. } \\
\text { Both teachers agreed that the books from the government were } \\
\text { still lacking and needed to be revised and needed to be based on } \\
\text { the environment. }\end{array}$ \\
\hline 3. & $\begin{array}{l}\text { Education with outdoor } \\
\text { learning }\end{array}$ & $\begin{array}{l}\text { Outdoor learning based on our friends' environmental subject was } \\
\text { rarely done. Outdoor learning was carried out occasionally if } \\
\text { there was only voluntary work. }\end{array}$ \\
\hline 4. & $\begin{array}{l}\text { The view of teaching } \\
\text { material of electronic } \\
\text { module based on outdoor } \\
\text { learning. }\end{array}$ & $\begin{array}{l}\text { Both teachers stated that in the environment of Kemalang } \\
\text { District, Klaten had no teaching material of electronic module } \\
\text { based on outdoor learning. They believed that if they use these } \\
\text { teaching materials, students will be better able to master the } \\
\text { material of our friend's environment because the material is } \\
\text { presented more deeply and can improve the activities of students' } \\
\text { experiences. }\end{array}$ \\
\hline
\end{tabular}

Based on the interview with the teacher obtained the learning styles of students, namely:

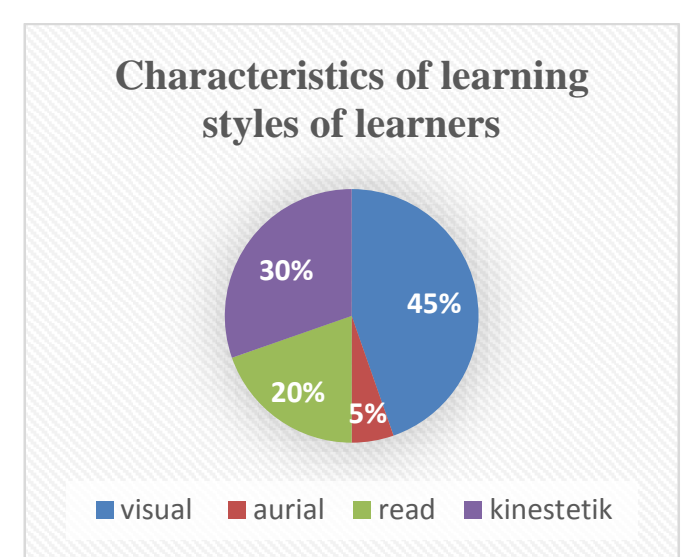

Figure 2. Characteristics of Learning Style of Learners

Based on Figure 2. it can be seen the percentage of students' learning styles. Students with a visual style category of only 25 students represented by $45 \%$, students with aural learning style 
(audio) amounted to 3 students represented 5\%, students with the Read (Text) category amounted to 11 students represented $20 \%$, and the remaining 11 students with $30 \%$ is a category of kinesthetic learning style. Therefore, it can be concluded from the four dominating categories are visual categories with the presentation of material in the form of images, animations, graphics, and videos. Based on the material in our friend's environment at the fifth-grade, It was known that learning still took place in the classroom with textbooks provided by the government. After the teacher knew the understanding of teaching material of electronic module with outdoor learning, the teacher believed that the need for teaching materials that can activate students in the learning process and based on the experience of students in everyday life. The teacher interviewed also stated that the need for interesting teaching materials was complemented by real environmental experiences in students' lives so that they did not become bored while studying. Experience provided a good opportunity for students [13]. Students also argued that they want interesting and fun teaching materials along with visualization of real images.

\subsection{Document Analysis}

Document analysis was carried out to find out the content and scope of the material contained in learning materials that were commonly used by teachers and students in learning. Learning resources analyzed in this study were thematic textbooks. The results of the document analysis can be seen in the following explanation:

1. Material included humans and the environment, environmental changes on our friend's environment material, but students just sit still looking at the images presented in the textbook.

2. There was material in the form of pictures and reading but students were not invited directly to the surrounding environment.

Based on the analysis of teaching materials that were often used, it turned out that the teaching material still had some disadvantages. These deficiencies were present in the presentation of material, and the visualization of images. Visualization was only in textbooks and done in the classroom. Though the presentation of the electronic module with motion pictures would be able to increase the imagination and motivation of participants. This was in line with the previous study from [14] that as a result of analyzing the data obtained from the research, it appeared that the motivation of students who used science process skills based on Physics module was better than conventional learning. The analysis was in line with a study from [15] which suggested that knowing the relevance of material that has been learned with daily life can provoke the curiosity of students to study well so as to improve their learning ability. This learning can be applied through the use of examples in everyday life as a bridge for students' understanding of the material that was enjoyable.

Based on the result of observation, interview, and document analysis, it was necessary to develop teaching material in the form of an electronic module based on outdoor learning to improve students' learning ability. Effective teaching material would help students experience activity so that learning was more meaningful and at the end, students can develop their learning ability. The teaching material was useful for the teacher as a guideline that would direct all of their activities in teaching and also constitute competency substances that must be taught to the students. In a study from [6] mentioned that educators, electronic module can be used to develop teaching material for elementary school students to teach. The teaching material was useful for students as a guideline that would direct all activities in the learning process and also constituted the substance of competence that must be learned [16]. 


\section{CONCLUSION}

Based on the result of the observation, it can be concluded that some students were still less enthusiastic because our friend's environmental material was presented with a textbook. The result of the interview, it can be concluded that the teaching materials used were still in the form of package textbooks from the government as well as students rarely undertaking to learn outside the classroom. The teacher was interested in being offered thematic module based on outdoor learning. Document analysis, it can be concluded that the teaching material commonly used still had several disadvantages, namely; the presentation of the material was incomplete, image visualization that did not encourage students' imagination which was connected with the daily living environment. Therefore, it was necessary to develop teaching material of electronic module based on outdoor learning to improve the learning outcomes of elementary school participants.

\section{REFERENCE}

[1] C. E. Glenn, "The holistic curriculum: Addressing the fundamental needs of the whole child in a diverse and global society," in National Forum of Multicultural Issues Journal, Vol. 6, No. 2, pp. 1-10, 2009.

[2] S. Mahmoudi, E. Jafari, H. A. Nasrabadi, and M. J. Liaghatdar, "Holistic education: An approach for 21 century.," Int. Educ. Stud., Vol. 5, No. 2, pp. 178-186, 2012.

[3] E. Suwarni, "Pengembangan Buku Ajar Berbasis Lokal Materi Keanekaragaman LabaLaba Di Kota Metro sebagai Sumber Belajar Alternatif Biologi untuk Siswa SMA Kelas X,” BIOEDUKASI (Jurnal Pendidik. Biol., Vol. 6, No. 2, 2015.

[4] I. J. S. Vina Serevina, Sunaryo, Raihanati, I Made Astra, "Development of E-Module Based on Problem Based Learning (PBL) on Heat and Temperature to Improve Student's Science Process Skill," TOJET Turkish Online J. Educ. Technol. -, Vol. 17, No. 3, pp. 2636, 2018.

[5] E. Peniati, "Pengembangan modul mata kuliah strategi belajar mengajar IPA berbasis hasil penelitian pembelajaran," J. Pendidik. IPA Indones., Vol. 1, No. 1, 2012.

[6] A. D. Yasa, D. D. Chrisyarani, S. Akbar, and A. Mudiono, "E-Module Based on Ncesoft Flip Book Maker for Primary School Students,” Vol. 7, pp. 286-289, 2018.

[7] A. Peña-rios, J. Pirker, C. Gütl, and M. Gardner, "EAI Endorsed Transactions Preface to the Special Issue on Immersive Environments: Challenges, Research and New Developments," Vol. 2, No. 6, pp. 2015-2016, 2016.

[8] H. Husamah, "PEMBELAJARAN LUAR KELAS (OUTDOOR LEARNING)," Res. Rep., 2013.

[9] E. Scotland, Outdoor Learning. .

[10] Sugiyono, Metode penelitian pendidikan:(pendekatan kuantitatif, kualitatif dan $R \& D$ ). Alfabeta, 2008.

[11] dan S. Miles, Mathew B.A, Michael Huberman, Analisis Data Kualitatif Buku Sumber tentang Metod-Metode Barule. 2009.

[12] A. Sari and C. Ditasona, "Developing Mathematics Module based on Realistic Mathematics Education (RME): Triangle Topic for 7 th grade of Junior High School," 2019.

[13] A. Matias and A. Aguilar-Gonzalez, "What do Geology and it have in Common? The Case of an International Collaboration through Experiential Learning," in Engaging Dissonance: Developing Mindful Global Citizenship in Higher Education, Emerald Publishing Limited, pp. 107-127, 2017. 
[14] F. A. Perdana, S. Sarwanto, S. Sukarmin, and I. Sujadi, "Development of e-module combining science process skills and dynamics motion material to increasing critical thinking skills and improve student learning motivation senior high school," Int. J. Sci. Appl. Sci. Conf. Ser., Vol. 1, No. 1, p. 45, 2017.

[15] Y. Agustyarini and J. Jailani, "Pengembangan bahan ajar matematika dengan pendekatan kontekstual dan metode penemuan terbimbing untuk meningkatkan EQ dan SQ siswa SMP Akselerasi," J. Ris. Pendidik. Mat., Vol. 2, No. 1, pp. 135-147, 2015.

[16] S. B. M. Hamdani, "Bandung: CV," Pustaka Setia, 2011.

[17] E. Z. Geh, "Organizational spiritual leadership of worlds 'made' and 'found' An experiential learning model for 'feel,", Leadersh. Organ. Dev. J., Vol. 35, No. 2, pp. 137 151, 2014. 